\begin{tabular}{|c|c|}
\hline $4 E$ European Association for the & $\begin{array}{c}\text { International Conference on Renewable Energies and Power Quality } \\
\text { (ICREPQ' 12) }\end{array}$ \\
$\begin{array}{c}\text { Development of Renewable Energies, Environment } \\
\text { and Power Quality (EA4EPQ) }\end{array}$ & Santiago de Compostela (Spain), 28th to 30th March, 2012 \\
\hline
\end{tabular}

\title{
Energy system aspect in Brazil
}

\author{
C. A. V. Carneiro ${ }^{1,2}$, J. C. S. Oliveira ${ }^{1}$ and A. B. Caldeira ${ }^{1}$ \\ ${ }^{1}$ Mechanical and Materials Engineering Department \\ IME, Military Institute of Engineering \\ Praça General Tibúrcio, 80 - Praia Vermelha - Rio de Janeiro, (Brazil) \\ Phone/Fax number: +00 5521 2546-7049, e-mail: cvieira@ime.eb.br,julio@ime.eb.br, aldelio@ime.eb.br \\ ${ }^{2}$ Mechanical Engineering Department \\ COPPE/UFRJ, Federal University of Rio de Janeiro \\ Campus Fundão Island - Technology Center, Block I, room 263, C.P. 68503, Rio de Janeiro, Brazil \\ Phone/Fax number: +00 5521 2562-8383, e-mail: vieira@mecanica.coppe.ufrj.br
}

\begin{abstract}
Brazilian energy matrix development has been dominated by hydropower due to the abundant natural relief. Additionally, small hydropower (SHP) is made within the country of difficult access, with the aim of providing energy in this region. On the other hand, there is the growth of alternative energies such as wind, thermal, thermonuclear, solar, and especially bioenergy, biofuels are observed. In turn, social and environmental impacts are studied as to minimize its effects in promoting more sustainable local neighborhood. Legal issues are fundamental to its environmental regulations so as to avoid the environmental impacts generated. This article describes the renewable energy alternatives that do not pollute the environment, and are used in the country, as well as the aspect of investment and financing in the Brazilian energy matrix.
\end{abstract}

\section{Keywords}

Brazilian energy, alternative energy, renewable energy, greenhouse gas emissions.

\section{Introduction}

Rising prices of fossil fuels and depending on oil reserves depletion has caused most countries to undertake find alternative sources of energy that allow mitigation of economic problems. In addition, social issues (employment, income, migration) and environmental (climate change and pollution) reinforce the need to use fuel produced by clean energy, resulting in the anticipated timeframes determined by oil shortage.

In fact, it is considered that the growing demand bioenergy in developed countries will occur primarily due to the society pressure through the fossil fuels exchange, based on environmental issues. The concentration of atmospheric $\mathrm{CO}_{2}$ has increased by $31 \%$ in the last 250 years. The numbers tend to increase significantly if gases emissions sources cause global warming, one of the most important being fossil fuels burning of are not controlled [1].
Through the Kyoto Protocol, discussed and negotiated in Japan in 1997 and in force since February 2005, several countries undertook to reduce the emission of gases causing the greenhouse effect is considered, according to most scientific research as the global warming cause. For this international treaty proposes a schedule by which developed countries have an obligation to reduce greenhouse gases amount by at least $5.2 \%$ in 2012 compared to 1990 levels.

Brazilian energy matrix verifies that the majority focuses on pollution sources and non-renewable resources such as oil derivatives, which, in order to regiment them, they created the National Petroleum Agency (NPA) [2]. The NPA provides the legal power to regulate and supervise the use of fuels, obviously with contributions directed to biofuel, allowed the work to grow the industry. In addition, the contribution of NPA would be the implementation of national policies on oil, natural gas and biofuel, the management of oil and natural gas from the Union, its regulations, the development agent and in the interests of the consumer: price, quality and availability of products as well as free competition and ensuring domestic supply of the product. On the other hand, the Agency does not control fuel prices, which are free, now in the country. The NPA function, in relation to prices, is to detect any uncompetitive practices and send them to the Brazilian competition which oversees all agencies.

In Brazil, the Ministry of Mines and Energy (MME) is the institution responsible the preparation of the basic principles and guidelines set national energy policy. As a subsidy, the Ministry promotes, through its organs and related companies, several studies and analysis oriented energy sector planning. In 2004, they created the Energy 
Research Company (EPC), in order to provide services in the area of studies and research to subsidize the energy sector planning, such as electricity, oil and natural gas and its derivatives, coal, renewable energy sources and energy efficiency, among others. The EPC develops and publishes the Brazilian Energy Balance (BEB) which documents and divulga1 annually, extensive research and accounts of supply and energy consumption in Brazil, covering the activities of extraction of primary energy resources, their conversion into forms secondary, import and export, distribution and end use of energy. In addition, preliminary data are published in the first half year after the base, allowing analysis of the behavior of the country and the production, processing and energy use are anticipated.

Analyzing the energy consumed in the country, it appears that the agricultural potential of Brazil to provide for possible expansion in the production of alternative renewable energy. However, sets up the conflict with the availability of natural resources, increasing food production and renewable energy to the process of development of the country

This article discusses the current Brazilian energy matrix in relative and absolute values, their strengths, future investments, social and environmental impacts that may arise and legal aspects for further regulation. A critical approach on certain energies that are in focus today, are also presented.

\section{Brazilian energy matrix}

Power generation in the country is mainly due to oil and oil products, natural gas, biodiesel, and electric power generation can say, briefly, wind, bagasse from sugar cane, steam coal and mineral form, so the Brazilian energy matrix. The data are obtained from various sources of public and private institutions, which are condensed and shown in the report of BEB in 2011 [3].

Looking at Table 1 shows that in 2010 the production of oil and natural gas increased by $5.3 \%$ and $8.5 \%$ compared to 2009 , respectively. In addition, domestic supply and power generation had a significant increase by $9.1 \%$ and $11.1 \%$ respectively in the previous year, but the consumption increased by $7.4 \%$, but with absolute values greater supply consumption, showing that the country does not need to import electricity ready for consumption. In turn, there was an increase by $1.2 \%$ in its population and $7.5 \%$ in its Gross Domestic Product (GDP), further increasing the per capita income in Brazil.

The growth of all energy sources in the period 2009-2010, is seen in figure 1, especially natural gas, whose domestic supply increased by $30.4 \%$ due to significant increases in production $(8.5 \%)$ and imports $(48 \%)$, and $31.3 \%$ reduction in burning and loss. The proportion of renewable energy in the Brazilian energy matrix in 2010 remained high, reaching $45.3 \%$. In 2010 , the total energy consumed in the country reached 270.8 million tons of oil equivalent (Mtoe), meaning an increase $11.0 \%$ over 2009.

Table 1. - Parameters energy values obtained in 2009 and 2010

\begin{tabular}{|l|r|r|r|r|}
\hline \multicolumn{1}{|c|}{ Parameter } & \multicolumn{1}{c|}{ Unit } & \multicolumn{1}{c|}{2010} & \multicolumn{1}{c|}{2009} & Variation \\
\hline Petroleum Production ${ }^{1}$ & $10^{3} \mathrm{bbl} / \mathrm{day}$ & $2.137,4$ & $2.029,0$ & $5,3 \%$ \\
\hline Natural Gas Production & $10^{6} \mathrm{~m}^{3} / \mathrm{day}$ & 62,8 & 57,9 & $8,5 \%$ \\
\hline Electricity Generation & $\mathrm{TWh}$ & 514,2 & 463,0 & $11,1 \%$ \\
\hline Liquid Fuel Consumption & $10^{6} \mathrm{bbl} / \mathrm{day}$ & 322,3 & 298,1 & $8,1 \%$ \\
\hline Electricity Consumption & $\mathrm{TWh}$ & 454,1 & 422,8 & $7,4 \%$ \\
\hline Domestic Energy Supply $^{2}$ & $10^{6}$ toe & 270,8 & 243,9 & $11,0 \%$ \\
\hline Domestic Electricity Supply $^{2}$ & $\mathrm{TWh}$ & 548,9 & 503,0 & $9,1 \%$ \\
\hline Population $^{3}$ & $10^{6}$ inhab & 190,8 & 188,5 & $1,2 \%$ \\
\hline Gross Domestic Product(GDP) $^{4}$ & $10^{9} \mathrm{US} \$$ & $2.087,7$ & 1942,2 & $7,5 \%$ \\
\hline
\end{tabular}

${ }^{1} \mathrm{bbl}=$ barrel, includes natural gas liquid

${ }^{2}$ includes self-production

${ }^{3}$ Population survey in 2010. For 2009 an estimate was made from the data of the IBGE, since the series has not yet been reviewed

${ }^{4}$ GDP by IBGE converted to US $\$$ average exchange rate for 2010 (Central Bank: US\$ $1,00=\mathrm{R} \$ 1,7603)$

It is observed that, for the period of 40 years, from 1970 to 2010 , there was a jump of more than $300 \%$ in the domestic energy supply and over $1100 \%$ in the electricity supply, as in Table 2 . Hence one can conclude that there was a federal government concern in 40 years, more power to the people, combining life comfort and quality for residents. Already, the population had increased by approximately $105 \%$ of people in Brazil and growth around $390 \%$ GDP.

Table 2. - Values of key parameters from 1970 to 2010.

\begin{tabular}{|l|c|c|c|c|c|c|c|}
\hline Parameters & Unit & 1970 & 1980 & 1990 & 2000 & 2009 & 2010 \\
\hline $\begin{array}{l}\text { Domestic } \\
\text { Energy } \\
\text { Supply }\end{array}$ & $10^{6}$ toe & 66,9 & 114,8 & 142,0 & 190,6 & 243,9 & 270,8 \\
\hline $\begin{array}{l}\text { Domestic } \\
\text { Electricity } \\
\text { Supply }\end{array}$ & TWh & 45,7 & 139,2 & 249,4 & 393,2 & 503,0 & 548,9 \\
\hline Population $^{2}$ & $10^{6}$ inhab & 93,1 & 118,6 & 146,6 & 169,8 & 188,5 & 190,8 \\
\hline GDP $^{3}$ & $10^{9}$ US\$ & 429,6 & 982,7 & $1.148,9$ & $1.469,2$ & 1942,2 & $2.087,7$ \\
\hline \\
includes self-production \\
2 Population survey in 2010. For 2009 an estimate was made from the data of the \\
IBGE, since the series has not yet been reviewed \\
3 Prices 2010
\end{tabular}

${ }^{3}$ Prices 2010

On the consumption side, in 2010, the residential sector grew at $1.9 \%$ mainly due to tax cuts policies of for some consumer goods during economic crisis, and increased per capita income. On the other hand, the industry experienced the largest increase in total energy demand occurred in the country, resulting in an increase by $13.0 \%$ over 2009, thus indicating a sector consistent recovery after the economic crisis.

In turn, the commercial, agricultural and public, when analyzed together, showed positive growth at $5.2 \%$ over the previous year. Already, the energy sector increased $7.0 \%$, whereas aggregates processing centers, the extraction processes and energy products internal transport, in its final form.

In addition, the diesel oil consumed in domestic market in 2010 , there was an increase by $10.2 \%$ at the same time; there is an increase by $8.3 \%$ in domestic production of sugar cane bagasse, an increase by $7.1 \%$ in ethanol, and $4.4 \%$ of hydrated alcohol in the previous year. Additionally, there is an increase by $14.6 \%$ in the production of anhydrous ethanol. Again, oil production is rising, and there is an increase by $17.5 \%$ in 2010 compared to 2009 because entry into four units operation. The fuel demand in the transportation sector increased by $10.8 \%$ compared to 2009 due primarily to growth in 
national vehicle fleet. But also, there was high ethanol and biodiesel production, which contributed high renewability premise national headquarters of transport sector increase by $17.5 \%$ against $3.0 \%$ increase in the global matrix of the same segment. Therefore, liquid fuels consumption sector increased by $8.1 \%$ in 2010 over previous year.

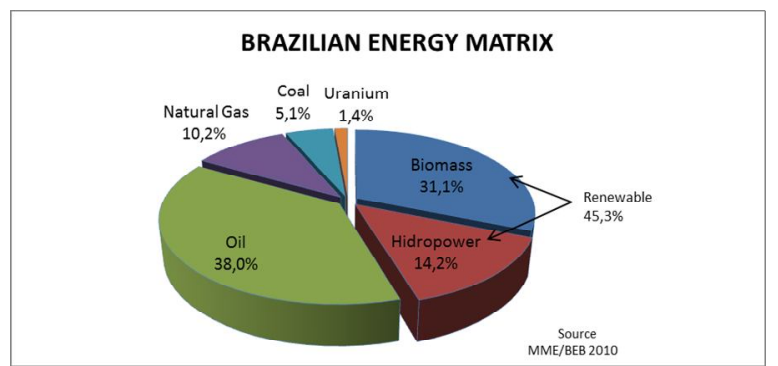

Figure 1. Chart of the energy matrix of Brazil in 2010, consisting of its primary energy sources

The graph in Figure 2 shows the structure of the Brazilian electricity supply in 2010. It may be noted that Brazil has a generation matrix of predominantly renewable electricity, and the internal hydraulic generation accounts for approximately $75 \%$ amount of the offer. Imports are mainly from renewable sources, it can be stated that approximately $81 \%$ of electricity in Brazil are derived from renewable sources, without taking into account the thermal generation share derived from biomass. Electricity production registered an increase by $9.1 \%$ in 2010 compared to 2009. Also, non-renewable sources increase by $48.2 \%$ in generation, compared to previous year, especially for natural gas and oil, with an increase of $139.4 \%$ and $170 \%$, respectively.

Already generation through renewable sources has increased by $5.0 \%$, and the wind was the highest growth up $50.5 \%$, because the installed power in 2009 , for wind generation in the country grew at $45.3 \%$, followed by biomass, an increase by $18.1 \%$. With the increased by use thermal power plants last year, the electricity from renewable sources decreased by $87.1 \%$ against $90.5 \%$ in 2009.

The case of Bolivia's gas forcefully exposed the weakness dependence on external energy resources. Natural gas is cleaner than oil, but it is also an option subject to local economy foreign decisions. The natural charcoal is also concentrated in a few regions, which are producing states in the region south of the country, and although the reserves are more durable, its strategic value in the global economy and his polluting power narrows the possibility of international spread of its use.

\section{Renewable primary energy sources}

In this section, we will present some inherent renewable energy characteristics do not pollute the environment, said clean. The geothermal, tidal, and hot fusion energies are not discussed, although this type of fit, not being exploited in Brazil. But, bioenergy that is classified as renewable primary sources, but they are polluting the atmosphere.

\section{A. Hydropower}

Brazilian energy matrix generates predominantly renewable electricity, and the internal hydraulic generation accounts for approximately $80 \%$ of offer.

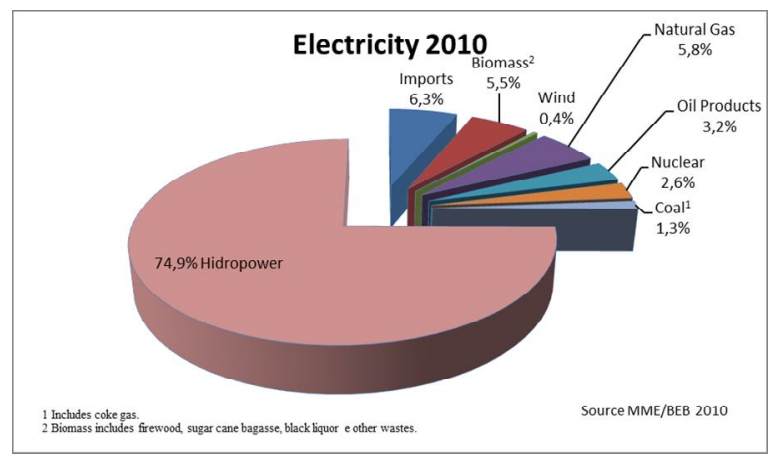

Figure 2. Chart of the Brazilian electricity supply in 2010 , consisting of its main sources of energy.

The country must have at least 30 hydropower plants by 2020, which will generate about 20 megawatts of energy. Moreover, six has already been authorized and should be operational from 2018. Other 24 are still dependent on approval and are expected to start functioning from 2016. The forecast is in the Ten Years Plan for Energy Expansion of 2020 (PEE), published by the Ministry of Mines and Energy [4]. The planning document provides the country's energy by 2020 and serves to guide the decisions of the government in meeting the growing demand and need for sector infrastructure.

Brazil is exploring its potential as a major source of hydroelectric power generation. The model was established from projects of large buses and construction of large transmission lines, consolidated in late 1980. However, given the need to adapt the concepts of renewable and clean energy to the most current indicators of sustainability, we must revisit the country's energy matrix and establish strategies for energy sector development. The last major crisis in the energy sector in 2001 should have been more forceful didactic effect, since it was timely to try to solve the problem that made use of one of the most effective means demand management has been in the news country: the overcharge of the abuse, in a progressive manner, and encouraging the rationalization through economy bonus.

Moreover, at the same time that Brazil has a strong environmental legislation, paradoxically, there is big problem of rivers siltation, streams, lakes and dams coming mainly from agricultural activities and the illegal occupation hillsides.

Currently, even though Brazil is the largest hydroelectric power world, water shortages in recent years coupled with the unfortunate episodes of rivers contamination, lakes and underground accumulations, and the conflicts between competing users, led to the formulation, on entirely new public policy for the water sector.

Among the many problems stemming from the removal of forest cover, and reduced biodiversity, has been observed in an ever more intense: severe floods (which 
occurred early in the year 2011 in the mountain region of Rio de Janeiro) and the rapid degradation of the soil (as seen in all countries of the world, particularly the least developed countries).

In industrialized economies, environmental problems are often associated with pollution, whose environmental policies are geared to reverse this situation and avoid further deterioration. With these measures, the patterns are restored water quality, air and soil before the crisis. In underdeveloped countries, the socio-environmental crisis is directly linked to depletion of its resource base. Therefore, policies should give priority to the rational management of natural resources.

\section{B. Wind Energy}

Among the renewable sources, solar and wind power are the ones that had the greatest growth in the world in recent years. Because they have large geographical opening, they can generate electricity close to load centers, eliminating the need for high voltages transmission lines.

When considering the repairs environmental costs are systematically increasing, wind power, which considered a clean energy, competes in the final cost with all other traditional forms of production. The wind farms are proven profitable and competitive return on capital employed. The verticality of the wind towers allows widespread by using the land under the turbines for farming and ranching. The used technology source is fully available. The most cited advantages of wind energy environmental point of view are striking. It prevents farmland flooding, population displacement, environment damage and leaves no residue or produce toxic gases. His influence on the physicochemical characteristics of the soil is void, does not influence the aquifer, replacing fossil fuels and avoids carbon dioxide emission, nitrogen oxides and sulfur dioxide. There are drawbacks to wind energy charged. Although decreases continuously, the domestic production cost is still higher than in electricity generation traditional forms. The air is light, so the machines are great. The air near the ground is slow due to the soil roughness. For this reason, you need tall towers. They cause visual impact, and are evident in places such as hills, back, open plains or plateaus, which increase the visual impact. The rotors rotation is not silent and appears evident within walking distance. They are also inadequate in the birds migratory routes. The global wind energy escalation has been dizzying. The goal is to generate $12 \%$ of electricity from wind sources.

Technological developments resulting from the efforts of the international scientific community and the companies involved increased use of wind turbines. The use of new materials and techniques have allowed the construction of larger blades, with appropriate flexibility and endurance, became lighter and stronger, and foundations and anchoring systems easier. Drive and control system new techniques of generating machines in variable speed drives were developed, tested and implemented. The operating range of the machines was increased at slower speeds, have become technically feasible. The gearbox, a noise major source was eliminated. The set became lighter. Until recently, the wind was favorable nesting only on the coast and sea. Three factors account for this selectivity: the relative safety of investors about the current availability of high average wind speed, the less friction between the wind and water encourages higher average speeds and lower in height from the ground, and land costs acquisition absence for offshore wind farms installation.

It should be noted the Northeast great potential produces about $75 \mathrm{MW}$. The second capability is the Southeast, the order of $30.000 \mathrm{MW}$, Southern Region, in order of 23.000 MW. And it is worth missing a lot to do to create and renew inventories wind power assessment in the Midwest Region, as it has been possible to verify and check hydro-wind complementarity Brazilian north and south, when we have seen periods of high winds (from September to March in the whole country) with periods of low hydro-wind. This contract allows us to think in hybrid, solar and hydro-wind systems ensure that energy in all months of the year in Brazil.

The study results show a synergy and wind/water where the shells of large hydro reservoirs would be the potential of wind power. What can help curb dependence on oil are the alternative energy. The number of wind farms in Brazil is expected to double over the next four years from the current 45 to 86 , making the participation of wind energy generated by the jump from $0.7 \%$ to $2.1 \%$ of the total electric power matrix of the country.

\section{Solar Energy}

Solar energy is the name given to any type of thermal energy capture from the sun, and subsequent transformation of this energy captured e. in some form, usable by man, either directly for heating water or as electrical or mechanical energy. In its movement around the Sun, the Earth receives $1,410 \mathrm{~W} / \mathrm{m}^{2}$ of energy measurement made on a surface normal (angle) with the sun, approximately $19 \%$ is absorbed by the atmosphere and are reflected by $35 \%$ clouds. When passing through Earth's atmosphere, most solar energy is in the form of visible light and ultraviolet light. Plants use this energy directly in the photosynthesis process. It uses this energy to burn wood or mineral fuels. There are experimental techniques to create fuel from the sunlight absorption in a chemical reaction in a similar manner to plant photosynthesis - but without the presence of these organisms. The spectrum of sunlight at Earth's surface is more widespread throughout the visible and infrared range and a small range of ultraviolet radiation [5].

Solar energy capture methods are classified as direct or indirect. The direct means there is only one change to a type of solar energy usable by man. Solar energy reaches a photovoltaic cell creating electricity. (The conversion from photovoltaic cells is classified as direct, although the electricity generated will need new conversion energy light or mechanical, for example. And solar energy reaches a dark surface and is transformed into heat, which heats a quantity of water, for example - this principle is widely used in solar water heaters. In turn, 
the indirect means you need to be more of a transformation to usable energy that arises, for example, systems that automatically control blinds, according to the availability of light from the sun, and can be divided into passive and active. Passive systems are generally straightforward, although it involved (sometimes) in convective flows, which is technically a conversion of heat into mechanical energy, and on the other hand, active systems are that appeal to electrical devices aid, mechanical or chemical to increase the collection effectiveness. The indirect systems are often also active.

The advantages of using solar energy are described as the energy does not pollute during their production. The pollution caused by manufacturing the equipment needed for the construction of solar panels is fully controllable using the currently existing forms of control, in turn, the plants require minimal maintenance. Solar panels are more powerful, while its cost has been decreasing, become an economically viable solution, excellent in remote or difficult to access because its installation on a small scale does not require huge investments in transmission lines. In tropical countries like Brazil, the use of solar energy is feasible in almost all the territory, and in places far from centers of energy production, its use helps to reduce the demand energy and, consequently, the energy loss that would occur in transmission.

Moreover, one can say that the disadvantages of a solar panel are to consume an enormous amount of energy to be manufactured. The energy to manufacture a solar panel can be greater than the energy generated [6]. Already, the prices are very high relative to other forms of energy, there is a variation in the quantities produced according to the weather situation (rain, snow), and that at night there is no production at all, which requires that there means for storing energy produced during the day in places where solar panels are not connected to the transmission of energy. And in local middle and high latitudes, suffer a severe drop in production during the winter months due to lower daily availability of solar energy.

In addition, photovoltaic generation is defined by current use depend on the semiconductor PN junction to separate charged particles by photo management. These new devices include photoelectrochemical and nanocrystals cells.

\section{Small Hydro Power ( SHP)}

The construction period of a SHP consists of a period much smaller than a large plant, average of two years, managing the enterprise deploy in less time. They are an important alternative, an environmentally sustainable option, without doubt, reduce environmental impacts. The impacts exist, but are certainly mitigated, considering those represent a socially responsible option. Therefore, planning should consider in formulating policies for the sector that small hydro power plants are important elements for the expansion of energy.

Small Hydro Power (SHP) represents a major focus of priority of BEA (Brazilian Electricity Agency) with respect to increasing the electricity supply in Brazil. Due to its characteristics - power plants with installed capacity over $1 \mathrm{MW}$ and less than or equal to $30 \mathrm{MW}$ and with the reservoir with an area equal to or less than 3 square kilometers, this type of project allows for better meeting load of the towns and regions rural.

With the construction of 122 new power plants, thermal plants based on fossil fuels must increase its stake in Brazilian electric energy matrix from $17.7 \%$ to $23.1 \%$ in the next three years. Meanwhile, the share of hydropower would fall by $72.5 \%$ to $64.4 \%$, even with the construction of 311 new plants. As a result, the Brazilian energy matrix, often praised for exploiting renewable sources should increase their reliance on non-renewable resources and more pollutants such as oil and gas. The data consist of a study released Tuesday by the Applied Economic Research Institute (AERI)[7].

Brazil is currently the energy matrix with lower emissions of greenhouse gases among industrialized nations. Renewable sources account for $45.9 \%$ of domestic energy supply in Brazil, an average much higher than the rest of the planet, only $12.9 \%$. This causes the average consumption in the country will be 1.34 tons of oil equivalent per year (toe), well below the developed countries, which is 4.69 toe, and also below the global consumption, 1.78 toe . But the forecast is that the fossil fuels consumption in the country increase from the current 1.34 toe to 1.49 toe, following the worldwide trend suggested by the International Energy Agency [8].

\section{Conclusion}

An approach to the situation which is currently the Brazilian energy matrix was performed. The main energies that make up this energy matrix were presented. The alternative energy renewable and non-renewable resources were discussed in detail, stating its capabilities and features. Future investments as well as the environmental aspects were presented and discussed, some established by the National Energy Plan (NEP) [8].

After the crisis in Libya, from February 2011, oil was up significantly and directly affects their customers, in particular, the major European countries. There was intervention by the UN Security Council and NATO, and over the country, affecting too much the value of oil in its reserves. This came to the world oil consumer, and economic analysts currently expect that the oil supply to fall in coming years, since the measure may exacerbate the decline in supply in the long run, if prices in the short cut, as described [9].

The hydropower plants electricity solution from with its expansion to the maximum, depending on the rivers topography, flooding and subsequent expropriation is that wind and solar power increases too much domestic production of energy. The SHP generates energy solutions to inner cities that are not covered by traditional energy sources. In the same way, biofuels are renewable and biodegradable and have many environmental advantages, including reduced emissions of carbon dioxide $\left(\mathrm{CO}_{2}\right)$, the absence of sulfur and less polluting particles generation. Already, the elephant grass, which is 
a biofuel, it is technically feasible to produce biomass as a source of energy and its use as carbon sequestration [10]. In parallel, alternative energy has helped the economic growth of countries that have adopted this measure.

A great discussion of the efficiencies and the prices of alternative energy have been taken up and was made possible through auction [11] to get at special values, as shown in table 3 , and the average price (US\$/MWh) wind energy shows cheaper than hydropower in this case.

Table 3.- Renewable energy systems efficiency

\begin{tabular}{|l|l|c|}
\hline & Efficiency & Prices (US\$/MWh) \\
\hline Hydropower system & $50-60 \%^{[13]}$ & $35-45^{[13]}$ \\
\hline Wind energy & $30-35 \%^{[12]}$ & $85-95^{[1]]}$ \\
\hline Solar energy system & $18-20 \%^{[14]}$ & $200,0-300,0^{[14]}$ \\
\hline SHP & $50-60 \%^{[13]}$ & $70,0-90,0^{[1]]}$ \\
\hline
\end{tabular}

Nuclear power is much discussed today, the country offers a solid alternative non-renewable energy, requires no fossil fuel, do not generate greenhouse gases and fight global warming, but represents a serious problem, its generation of radioactive waste, which is usually low, affecting the safety issue. On the other hand, the scientific and technological knowledge acquired is beneficial to the country development $\mathrm{a}$ and for the scientific research advancement. Unfortunately, some representatives identities against nuclear energy in Brazil report that the country should follow the same path that other countries are reassessing their nuclear projects, taking radical stances discontinuing their investments due to safety issues.

Finally, Brazil will be able to investment planning, technology and proper management of all national resources, both renewable and nonrenewable, enjoy this century of wide energy security, generating exportable surpluses and finally reach the level of development we all desire.

\section{References}

[1] Bacchi, M. R, P. , Brasil - gerando energia de biomassa, limpa e renovável, CEPEA, jul 2006. Available in: <www.cepea.esalq.usp.br/ especialagro/ EspecialAgro Cepea_4.doc>.Accessed on 07/01/2011.

[2] Resolution NPA $N^{\circ} 16$, at 06/17/2008.National Petroleum Agency.

[3] Final Report 2011, Brazilian Energy Balance, Energy Research Company, Ministery of Mines and Energy. Available in: < https://ben.epe.gov.br/BENRelatorioFinal 2010.aspx $>$. Accessed on 11/22/2011.

[4] Brazil Agency, Available in: <http://www.saocarlosagora. com.br/brasil/noticia/2011/06/03/18500/plano-de-expansao de-energia-preve-mais-30-usinas-hidreletricas-ate-2020/> . Accessed on 06/30/2011.

[5] Earth Radiation Budget/Environmental Science/ Rutgers, Overview of Earth Radiation Budget, The University of New Jersey. Available in: <http://marine. rutgers. edu/ mrs/ education/class/yuri/erb.html>. Acessed on 07/02/2011.
[6] Cloudy Outlook For Solar Panels: Costs Substantially Eclipse Benefits, Study Shows, University of California, Berkeley, Science Daily, 2008. Available in: <http://www.sciencedaily.com/releases/2008/02/080220 224901.htm>. Accessed on 09/23/2009.

[7] Brazilian Energy Planning 2030 / Ministery of Mines and Energy; collaboration Energy Research Company. Brasília, MME, ERC, 2007.

[8] Thermoelectric gain weight in the brazilian energy matrix, Sustainable Planet, 02/16/2011. Available in: <http:// planetasustentavel.abril.com.br/noticias/mais-poluentetermeletrica-ganha-peso-matriz-energetica-18809.shtml > . Accessed on 06/27/2011.

[9] Market, Folha de São Paulo. Available in: <http://www. sindicombustiveis-pe.org.br/ comunicacao. php? id=127>. Accessed on 07/03/2011.

[10] Vilela. H. \& Cerize, D., Elephantgrass Paradise in power generation. Available in: <http:// www.agronomia.com. br/conteudo/artigos/artigos_capim_elefante_paraiso_gerac ao_energia.htm>. Accessed on 07/01/2011.

[11] Carolina Marcondes, O Globo Magazine, Economy, São Paulo, 08/27/2011. Available in: < http://oglobo.globo. com/economia/preco-de-biomassa-pchs-supera-de-eolicasem-leiloes-da-aneel-2959874>. Accessed on 01/18/2011.

[12]Terciote, Ricardo. Wind Turbine Efficiency for System Isolated - UNICAMP - Campinas - SP - 2001. Accessed on $01 / 18 / 2011$.

[13] Encina, A. S. A., Santos, E. F., Cicogna, M. A., Filho, S. S. e Ohishi, T., Optimal Performance criterion for generating units, Expert Symposium on Operating Hydroelectric Plants, $3^{\circ}$ SEPOCH, Foz do Iguaçu, Paraná, 2002.

[14] Brazilian Electricity Agency (ANEEL), Solar Energy, Chapter 3. MME, 2004.

[15] Martins, F.R., et al. Wind Energy utilization - 2008. Accessed on 01/18/2011. Revista Brasileira de Ensino de Física - São José dos Campos - SP. Available in: http://www.sbfísica.org.br.

[16] Shayani, R. A., Oliveira, M. A. G. e Camargo, I. M. T., Photovoltaic Solar Energy Cost and Conventional Sources Comparison, Brazilian Congress for Energy Planning, V CBPE, Brasília - DF, 2006. 